\title{
Molecular and cytogenetic studies of the Prader-Willi syndrome
}

\author{
R J Trent, F Volpato, A Smith, R Lindeman, M-K Wong, G Warne, E Haan
}

\begin{abstract}
Twenty-seven subjects with the Prader-Willi syndrome (PWS) were studied. Sixteen (59\%) had a cytogenetic deletion involving chromosome 15q11-13. Nine were non-deletional and two patients had structural rearrangements of chromosome 15: 47,XY, +del(15)(pter $\rightarrow$ q12), $\operatorname{var}(15)(p 11)$ and 45,XX,t(14q15q). At the DNA level, a greater proportion of patients $(74 \%)$ showed loss of one chromosome 15q11-13 allele using a combination of densitometry and RFLP analysis. Deletion sizes were variable with 13 of 20 detectable both cytogenetically and with probe pML34 (D15S9). The remaining seven had microdeletions at the pML34 locus. Heterogeneity was further seen in three subjects who had cytogenetic deletions but normal DNA studies. In one patient there was evidence of a duplication at the pML34 locus. A new molecular rearrangement was identified with probe p3.21 (D15S10) in two patients
\end{abstract}

Department of Molecular Genetics, Royal Prince Alfred Hospital, Camperdown, NSW 2050, and Department of Medicine, University of Sydney, NSW 2006, Australia.

R J Trent, F Volpato, R Lindeman, M-K Wong

Cytogenetics Unit, Oliver Latham Laboratory, Department of Health, North Ryde, NSW, Australia.

A Smith

Endocrinology and Diabetes Department, Royal Children's Hospital, Melbourne, Victoria, Australia. G Warne

Department of Medical Genetics, Adelaide Children's Hospital, Adelaide, SA, Australia. E Haan

Correspondence to Professor Trent.

Received for publication 17 September 1990.

Revised version accepted for publication 19 February 1991. and their mothers. Fifteen family studies were performed. In all 10 families where there was a molecular deletion, this was shown to have arisen de novo. DNA mapping confirmed that the paternal 15q allele was lost in three patients with PWS.

The Prader-Willi syndrome (PWS) is a rare multisystem disorder. Clinical features include hypotonia, hypogonadism, hypopigmentation, mental retardation, and obesity. The latter two are particularly significant in the natural history of this disorder. Mental retardation is usually not severe (mean IQ 60 with a range of 20 to 80 ), but obesity is a major clinical and psychosocial problem. ${ }^{1}$ The newborn with PWS is floppy, sucks poorly, and fails to thrive. However, appetite increases rapidly at approximately 3 to 4 years of age. By the teens, excessive eating produces gross obesity. The diagnosis of PWS may be suggested in the neonatal period but cannot be made conclusively until early childhood. Thus, there is delay in initiating appropriate management. $^{2}$

The aetiology of the PWS is unknown. Almost invariably only one member of the family is affected. However, some cases of familial recurrence have been described. ${ }^{3}$ Cytogenetic deletions involving the long arm of chromosome 15 were first described in 1981 and approximately half the patients with PWS have an interstitial deletion of 15q11-13.4 Five percent of patients have duplications or translocations while the remainder have normal karyotypes. ${ }^{56}$ DNA probes specific for the 15q11-13 region are now available. ${ }^{78}$ These have been used to characterise further the putative PWS locus called PWCR (Prader-Willi chromosome region). Recent results using these probes have provided further evidence that genomic imprinting secondary to loss of the paternal $15 \mathrm{q}$ locus is implicated in the pathogenesis of PWS. ${ }^{9}$ The present study describes DNA and 
cytogenetic findings in 27 patients with PWS, which is the largest cohort investigated in this way.

\section{Patients and methods PATIENTS}

This group comprised 27 patients in whom clinical histories and phenotypes were entirely consistent with PWS. These included early stage I phase of neonatal hypotonia and failure to thrive, hypogenitalism in the male, followed by hyperphagia in early childhood, mental retardation, short stature, typical facies, small hands and feet, and a behavioural disorder. Twenty-four patients had been followed over a period of time. ${ }^{10}$ They were recently reviewed and three additional patients were added to this study.

\section{DNA STUDIES}

\section{Detection of a new DNA restriction map}

DNA was isolated from buffy coats obtained from $10 \mathrm{ml}$ of blood. Aliquots of DNA $(10 \mu \mathrm{g})$ were digested with restriction endonucleases BamHI, EcoRI, HindIII, and BglII. Additional restriction enzymes were used where indicated below. Digested DNA was electrophoresed on $0.8 \%$ agarose gels and then transferred to nylon membranes by Southern blotting. Membranes were hybridised to ${ }^{32} \mathrm{P}$ labelled DNA probes and washed using stringent conditions $\left(0.1 \times S S C\right.$ at $65^{\circ} \mathrm{C}$ for 60 minutes). ${ }^{11} P W C R$ specific DNA probes included pML34 (D15S9), p3.21 (D15S10) (donated by the late Professor S Latt, Boston), and 85(2.4) (D15S53) (donated by Professor F-T Kao, Denver). DNA polymorphisms identifiable with probes pML34 (ScaI, allele frequencies: $6.5 \mathrm{~kb}-0.72 ; 6.3 \mathrm{~kb}-0.28$ ), p3.21 (TaqI, allele frequencies: $9.0 \mathrm{~kb}-0.83 ; 8.2 \mathrm{~kb}-0.17)$, and a multiallelic $(C M W 1)$ probe $(E c o R I)$ were sought. ${ }^{12-14}$ The CMW 1 probe was provided by $\mathrm{Dr} \mathrm{D}$ Ledbetter (Houston). The $3^{\prime} \alpha$ HVR probe (a gift from Dr D R Higgs, Oxford) was used for paternity testing. ${ }^{15}$ For the latter, filters were hybridised at $55^{\circ} \mathrm{C}$ and washed in $5 \times$ SSC.

\section{Detection of loss of one PWCR specific allele}

Membranes containing DNA digested with the restriction endonuclease HindIII were hybridised simultaneously to three DNA probes, pML34, OP1, and a $\beta$ globin gene probe (Pst $\beta$ ) located on chromosome 11p15 (Pst $\beta$ was donated by Professor T Maniatis, Boston). Probe OP1 is a $2.4 \mathrm{~kb} H$ incII insert in plasmid pBluescript. It was isolated from an EMBL3 phage library prepared from normal
DNA partially digested with $M b o I$. The library was screened with probe $\mathrm{p} 3.21$ and so probe OP1 is located within 20 to $25 \mathrm{~kb}$ of p3.21 (Lindeman et al, in preparation). Band sizes obtained for the above HindIII digests were $6.0 \mathrm{~kb}$ (pML34), $3.0 \mathrm{~kb}$ (OP1), and $7.8 \mathrm{~kb}$ ( $\beta$ globin). Autoradiographs were scanned in an LKB 2202 Ultroscan Laser Densitometer. Normal DNA samples were included in all membranes to control for hybridisation and washing conditions. Autoradiograph band intensities and densitometric traces of bands identified by probes pML34 and OP1 were scored by three observers (RJT, RL, M-KW) as representing normal, reduced, or increased intensities compared to the control $\beta$ globin.

Family studies

Both parents of 15 patients were studied.

\section{KARYOTYPE ANALYSIS}

Peripheral blood cultures were set up for high resolution banding after the method of Yunis ${ }^{16}$; $0.3 \mathrm{ml}$ of blood were added to $4.5 \mathrm{ml}$ of medium (either Ham's F10 or Iscoves, Flow Laboratory). After 48 hours, the cultures were blocked with $0.05 \mathrm{ml}$ of a methotrexate solution $\left(10^{-5} \mathrm{~mol} / \mathrm{l}\right)$ and reincubated for 17 hours overnight at $37^{\circ} \mathrm{C}$. The following morning the methotrexate was washed out and the block released with fresh medium to which $0.05 \mathrm{ml}\left(10^{-3} \mathrm{~mol} / \mathrm{l}\right)$ thymidine were added. The cultures were then incubated at $37^{\circ} \mathrm{C}$ for a further six hours. Harvesting was performed with colcemid (final concentration $1 \mu \mathrm{g} / \mathrm{ml}$ ) for 15 minutes, hypotonic $0.075 \mathrm{~mol} / 1 \mathrm{KCl}$ for 10 minutes, and fixed for one hour with 3:1 methanol:acetic acid. Slides were placed in a $37^{\circ} \mathrm{C}$ incubator for two to three days before GTG banding. ${ }^{17}$ A total of 15 to 20 cells was examined in each case. On scanning under the microscope, metaphase spreads were chosen for the criteria of a band stage of resolution greater than 750 bands plus readily distinguishable chromosomes 15 which were reasonably straight and not involved in a crossover. Chromosome 15 was scored as deleted when the q12 band was not seen and was not based on the absolute length of the q11-13 region (fig 1). Other banding techniques were used as indicated.

\section{Results}

PATIENTS

Sex distribution for the PWS patients was 21 males and six females. The predominance of males (21:6) may reflect bias in terms of recognising PWS more 


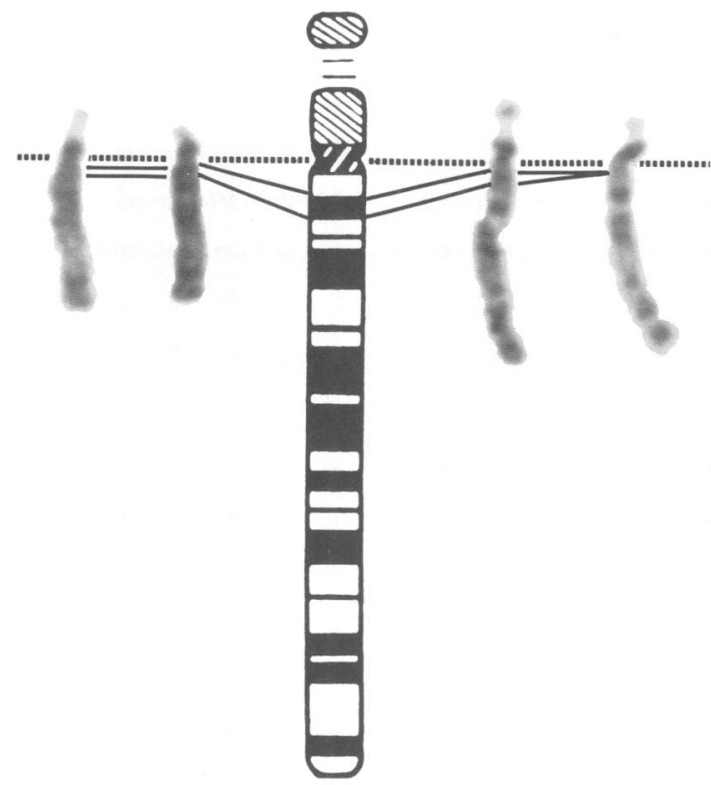

Figure 1 Ideogram of chromosome 15 in the centre shows the bands at the 850 band stage. On the left are normal chromosome 15 from patient 11 and on the right is a deleted chromosome 15 (patient 9). The broken line joins the centromeres in each case and the solid line the 112 band.

easily in males. Ages ranged from 4 to 30 years (table).

\section{DNA STUDIES}

New DNA restriction map

Digestion of normal DNA with the restriction enzyme BamHI and hybridisation to probe $\mathrm{p} 3 \cdot 21$ gives a normal restriction fragment of $25 \mathrm{~kb}$. Two unrelated males (patients 4 and 5) with PWS showed only an abnormal $20 \mathrm{~kb}$ restriction fragment. In the above two cases, maternal DNA had both the normal $25 \mathrm{~kb}$ and the new $20 \mathrm{~kb}$ restriction fragments. DNA samples from the respective fathers had the normal restriction fragment (fig 2, table). One of the above two patients (No 5) and his mother had an additional new band detectable with probe $85(2 \cdot 4)$ and the restriction enzyme EcoRI. All other restriction enzyme digests (HindIII, BglII, BclI, TaqI, $X m n \mathrm{I}, X b a \mathrm{I}, E c o \mathrm{RV}, H i n c \mathrm{II}, P s t \mathrm{I})$ in patients 4 and 5 were normal with both $\mathrm{p} 3 \cdot 21$ and $85(2 \cdot 4)$ probes. The two new restriction fragments described above were found in separate DNA preparations but not seen in 167 (BamHI) and 57 (EcoRI) normal DNA samples (total 334 and 114 chromosomes respectively). DNA from the remaining 25 PWS patients did not show abnormal bands when studied with probes pML34, p3.21, 85(2.4), and restriction enzymes BamHI, EcoRI, HindIII, and BglII.

\section{Loss of one PWCR specific allele}

Normal DNA maps do not exclude extensive deletions of one allele. These were sought in the $P W C R$ locus by comparing intensities in autoradiograph bands. Intensity changes were detected with probe pML34. These showed that 20 patients (Nos 1 to 10 and 16 to 25) had loss of one allele, while six (Nos 11, 13 to 15,26 , and 27) were normal in this respect (fig 3, table). In the remaining case (No 12), there was increased intensity in the DNA band. Densitometry changes with probe OP1 were consistent with the pML34 results in all but six cases (patients 3,10, $12,14,16$, and 17). In these instances, intensities of hybridisation bands were considered equivocal (table).

\section{DNA family studies}

RFLPs (ScaI with probe pML34 and TaqI with probe $\mathrm{p} 3.21$ ) were informative in only two of the 15 families studied. The ScaI (pML34) RFLP showed loss of the paternal $15 q$ allele in case 9 . In the same family, the multiallelic CMW 1 DNA probe detected the paternal allele at this locus (fig 4). Non-paternity was excluded by use of a second VNTR probe $\left(3^{\prime} \alpha\right.$ HVR) (data not shown). In a second family (No 14) the two ScaI alleles were present in the PWS patient thereby confirming the normal pML34 densitometry result at this locus (table). DNA samples from parents of 10 patients (Nos 1 to 10) with loss of one allele were also studied by densitometry. Both alleles in all parental DNA samples were present (table).

\section{KARYOTYPE ANALYSES}

Sixteen (Nos 3, 6, 8 to 10,13 to $19,21,23$ to 25 ) of the 27 PWS patients $(59 \%)$ had a deletion of $15 q$ detectable on cytogenetic studies and nine (Nos 1, 2, $4,5,7,11,20,22,27)$ patients $(33 \%)$ were normal (fig 1). Of the remaining two (7\%), one (No 26) had a familial Robertsonian translocation involving chromosomes 14 and $15 .{ }^{18}$ The second (No 12) had an additional 15 marker chromosome. ${ }^{19}$ A comparison of cytogenetic and DNA studies in the 27 patients is given in the table.

\section{Discussion}

In the present study cytogenetic deletions involving chromosome 15q11-13 were found in $59 \%$ of patients with PWS. A higher proportion (74\%) showed a deletion at the 15q11-13 locus by DNA 
Cytogenetic and DNA findings in 27 patients with PWS.

\begin{tabular}{|c|c|c|c|c|c|}
\hline \multirow[t]{2}{*}{ Case No } & \multirow[t]{2}{*}{ Sex/age (y) } & \multirow[t]{2}{*}{ Karyotype } & \multicolumn{2}{|c|}{ Densitometry } & \multirow[t]{2}{*}{ Parental origin } \\
\hline & & & pML34 & OP1 & \\
\hline $\begin{array}{l}1 \\
2 \\
3\end{array}$ & $\begin{array}{l}\text { M4 } \\
\text { M10 } \\
\text { M12 }\end{array}$ & $\begin{array}{l}\text { 46,XY } \\
46, X Y \\
46, X Y, \\
\operatorname{del}(15 q)\end{array}$ & $\begin{array}{l}\text { Deletion* } \\
\text { Deletion } \\
\text { Deletion }\end{array}$ & $\begin{array}{l}\text { Deletion } \\
\text { Deletion } \\
\text { Equivocal }\end{array}$ & $\begin{array}{l}\text { Indeterminate } \\
\text { Indeterminate } \\
\text { Indeterminate }\end{array}$ \\
\hline $\begin{array}{l}4 \\
5 \\
6\end{array}$ & $\begin{array}{l}\text { M14 } \\
\text { M19 } \\
\text { M26 }\end{array}$ & $\begin{array}{l}47, X X Y \\
46, X Y \\
46, X Y, \\
\operatorname{del}(15 q)\end{array}$ & $\begin{array}{l}\text { Deletion } \\
\text { Deletion } \\
\text { Deletion }\end{array}$ & $\begin{array}{l}\text { Deletion } \\
\text { Deletion } \\
\text { Deletion }\end{array}$ & $\begin{array}{l}\text { Paternal deleted } \\
\text { Paternal deleted } \\
\text { Indeterminate }\end{array}$ \\
\hline $\begin{array}{l}7 \\
8\end{array}$ & $\begin{array}{l}\text { M19 } \\
\text { M8 }\end{array}$ & $\begin{array}{l}\text { 46,XY } \\
46, X Y \\
\operatorname{del}(15 q)\end{array}$ & $\begin{array}{l}\text { Deletion } \\
\text { Deletion }\end{array}$ & $\begin{array}{l}\text { Deletion } \\
\text { Deletion }\end{array}$ & $\begin{array}{l}\text { Indeterminate } \\
\text { Indeterminate }\end{array}$ \\
\hline 9 & M21 & $\begin{array}{l}46, X Y \\
\operatorname{del}(15 q)\end{array}$ & Deletion & Deletion & Paternal deleted \\
\hline 10 & M9 & $\begin{array}{l}\text { 46,XY, } \\
\operatorname{del}(15 q)\end{array}$ & Deletion & Equivocal & Indeterminate \\
\hline $\begin{array}{l}11 \\
12\end{array}$ & $\begin{array}{l}\text { M14 } \\
\text { M13 }\end{array}$ & $\begin{array}{l}46, X Y \\
47, X Y,+ \\
\operatorname{del}(15) \\
(p t e r \rightarrow q 12), \\
\operatorname{var}(15)(p 11)\end{array}$ & $\begin{array}{l}\text { Normal } \\
\text { Duplication }\end{array}$ & $\begin{array}{l}\text { Normal } \\
\text { Equivocal }\end{array}$ & $\begin{array}{l}\text { Indeterminate } \\
\text { Indeterminate }\end{array}$ \\
\hline 13 & M12 & $\begin{array}{l}\text { 46,XY, } \\
\operatorname{del}(15 q)\end{array}$ & Normal & Normal & Indeterminate \\
\hline 14 & F27 & $\begin{array}{l}46, X X \\
\operatorname{del}(15 q)\end{array}$ & Normal & Equivocal & Indeterminate \\
\hline 15 & M6 & $\begin{array}{l}46, X Y, \\
\operatorname{del}(15 q)\end{array}$ & Normal & Normal & Indeterminate \\
\hline 16 & M18 & $\begin{array}{l}46, X Y, \\
\operatorname{del}(15 \mathrm{q})\end{array}$ & Deletion & Equivocal & Not studied \\
\hline 17 & M16 & $\begin{array}{l}\text { 46,XY, } \\
\operatorname{del}(15 q)\end{array}$ & Deletion & Equivocal & Not studied \\
\hline 18 & M12 & $\begin{array}{l}46, X Y \\
\operatorname{del}(15 q)\end{array}$ & Deletion & Deletion & Not studied \\
\hline 19 & M17 & $\begin{array}{l}46, X Y, \\
\operatorname{del}(15 q)\end{array}$ & Deletion & Deletion & Not studied \\
\hline $\begin{array}{l}20 \\
21\end{array}$ & $\begin{array}{l}\text { F16 } \\
\text { F18 }\end{array}$ & $\begin{array}{l}46, X X \\
46, X X \\
\operatorname{del}(15 q)\end{array}$ & $\begin{array}{l}\text { Deletion } \\
\text { Deletion }\end{array}$ & $\begin{array}{l}\text { Deletion } \\
\text { Deletion }\end{array}$ & $\begin{array}{l}\text { Not studied } \\
\text { Not studied }\end{array}$ \\
\hline $\begin{array}{l}22 \\
23\end{array}$ & $\begin{array}{l}\text { M10 } \\
\text { M5 }\end{array}$ & $\begin{array}{l}46, X Y \\
46, X Y \\
\operatorname{del}(15 q)\end{array}$ & $\begin{array}{l}\text { Deletion } \\
\text { Deletion }\end{array}$ & $\begin{array}{l}\text { Deletion } \\
\text { Deletion }\end{array}$ & $\begin{array}{l}\text { Not studied } \\
\text { Not studied }\end{array}$ \\
\hline 24 & F5 & $\begin{array}{l}\text { 46,XX, } \\
\text { del(15q) }\end{array}$ & Deletion & Deletion & Not studied \\
\hline 25 & M8 & $\begin{array}{l}\text { 46,XY, } \\
\operatorname{del}(15 q)\end{array}$ & Deletion & Deletion & Not studied \\
\hline 26 & F30 & $\begin{array}{l}45, X X, t \\
(14 q 15 q)\end{array}$ & Normal & Normal & Not studied \\
\hline 27 & F19 & $46, \mathrm{XX}$ & Normal & Normal & Not studied \\
\hline
\end{tabular}

*DNA deletions in patients 1 to 10 are not present in their parents. Microdeletions were found in patients 1, 2, 4, 5, 7, 20, and 22. DNA densitometry results at the pML34 locus in patients 9 and 14 were confirmed by RFLP patterns.

mapping. Using a similar combination of densitometry and RFLP analysis others have described variable changes at $P W C R$. In one report of 10 patients, six of nine had loss of the pML34 locus. More variable results were found at the $\mathrm{p} 3 \cdot 21$ locus: normal (3/8), deleted $(2 / 8)$, duplicated $(3 / 8) .{ }^{12}$ In the latter study four $P W C R$ specific DNA probes (D15S9, D15S10, D15S11, D15S12) were used. Despite this, identification of deletions in four patients relied entirely on densitometric analysis. None of the deletions in the 10 patients was fully characterised on the basis of RFLP data alone. Knoll et $a l^{20}$ using the same approach analysed DNA from PWS and Angelman's syndrome and categorised patients into three classes (I, II, III). Deletional heterogeneity observed in these two studies was also found in the present report with 20 of 27 PWS patients showing loss of one allele involving at least the pML34 locus; one patient had a duplication at pML34 and two had a DNA rearrangement at the p3.21 locus. The 27 PWS patients can be grouped into the classes proposed by Knoll et al, ${ }^{20}$ that is, class III is non-deletional, class II involves loss of the pML34/p3.21 locus, and class I is characterised by larger deletions which are also present cytogenetically. These data provide further evidence that PWCR plays a central role in the pathogenesis of PWS. However, the significance of molecular changes reported to date remains unclear and more extensive study of $P W C R$ is required.

Interpretations based on intensities of autoradiographs can be subjective and may be influenced by 

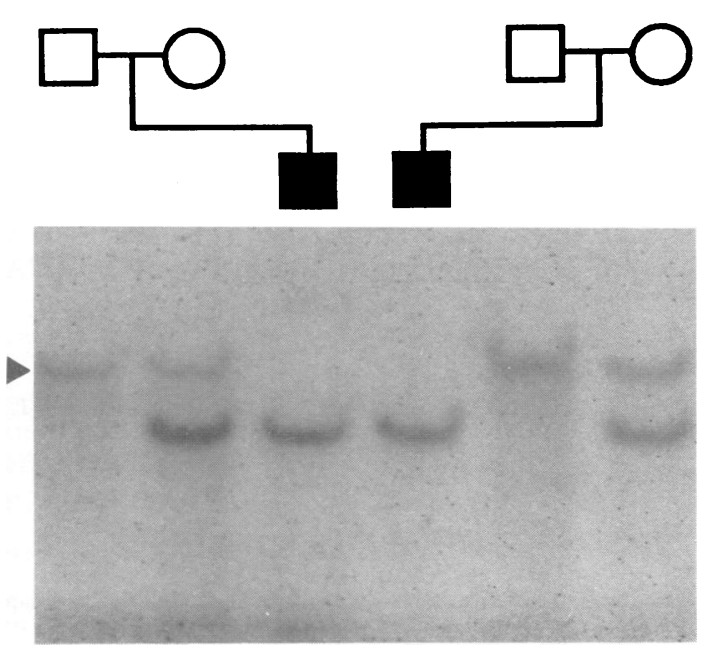

Figure 2 DNA mapping patterns for two PWS patients with new restriction fragments identified by the restriction enzyme BamHI and probe $3 \cdot 21$. The normal restriction

fragment (arrowhead) is present in the two paternal DNA samples. Maternal DNA shows both the normal $25 \mathrm{~kb}$ band and the new $20 \mathrm{~kb}$ fragment. Both patients with PWS (ם) have inherited the new (maternal) band but not the normal (paternal) allele.

technical variables, including the quantity of DNA present, the uniformity of DNA transfer, hybridisation, and washing. In the present study the inherent variability was reduced by incorporating an internal control ( $\beta$ globin) within each filter track. Plasmid p3.21 did not give a HindIII restriction fragment of comparable size to pML34 or $\beta$ globin and so was replaced by the closely related probe OP1. The latter was more helpful but still proved difficult to interpret in some cases. In this context, it is interesting that Gregory et al ${ }^{12}$ were unable to analyse this locus in two of 10 patients because of weak hybridisation signals with probe $\mathrm{p} 3 \cdot 21$. Until more definitive mapping data based on pulsed field gel electrophoresis are available, the exact extent of the PWCR related deletions must remain speculative.

Three subjects (Nos 13 to 15) had cytogenetic deletions but normal DNA maps. These could represent DNA rearrangements which were not detected with the probes available or the DNA changes were outside the cytogenetically deleted locus. Donlon ${ }^{21}$ has reported one PWS patient (DON-5) with a similar finding when studied with multiple probes including pML34 and p3.21. One subject (No 26) had a Robertsonian translocation involving chromosomes 14 and 15 . The same abnormality was present in the patient's mother and her brother and sister. ${ }^{18}$ Normal phenotypes in all the above family members would exclude this rearrangement as the sole factor in the pathogenesis of PWS. In this situation, a paternal abnormality of chromosome 15 is suggested (see below). A second interesting cytogenetic finding involved an extra segment of chromosome 15 . This was a de novo mutation in the patient (No 12). ${ }^{19}$ DNA intensity studies were consistent with additional chromosome $15 \mathrm{q}$ material.

Two subjects (Nos 4 and 5) had normal karyotypes. DNA analysis showed loss of one PWCR specific allele as well as a new restriction enzyme map detectable with BamHI and probe p3.21. In both cases maternal DNA had a similar abnormal band (fig 2). The molecular basis for this unique finding remains to be determined. One consideration is a DNA polymorphism since a new band was
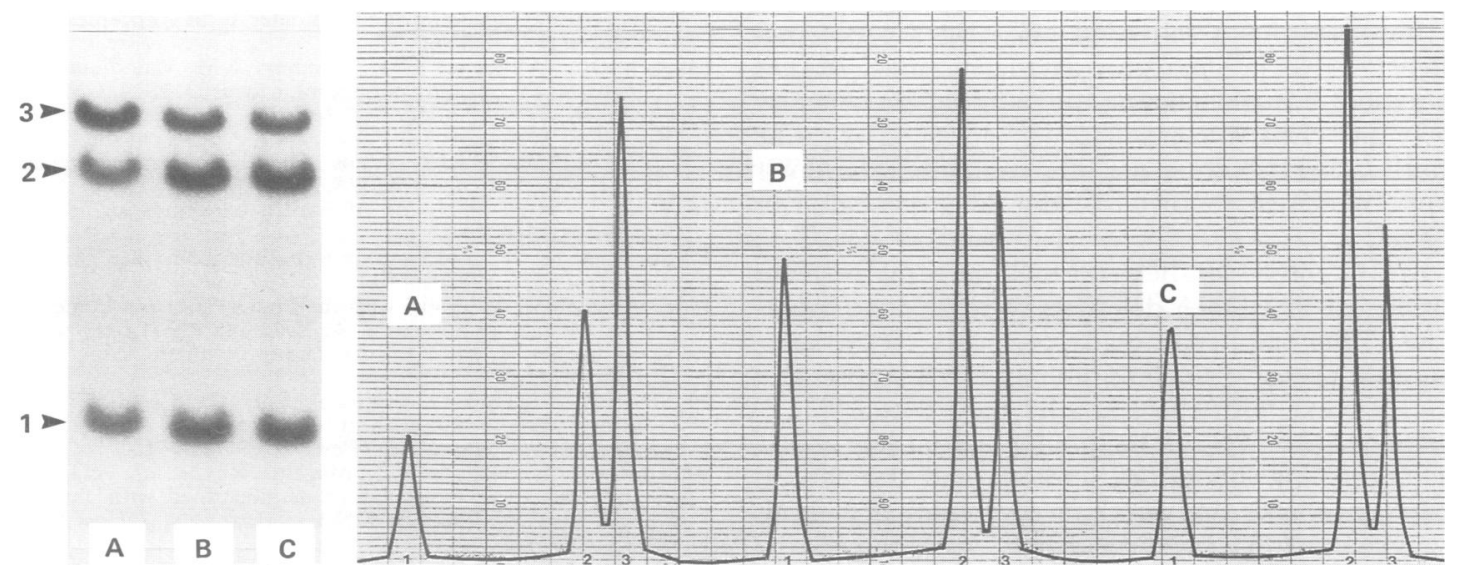

Figure 3 Southern blots and densitometric traces in patient 7 ( $A$ ), his father (B), and mother (C). The three DNA bands/densitometry patterns produced by restriction enzyme HindIII are identified by probes: (1) OP1, (2) pML34, and (3) B globin. 


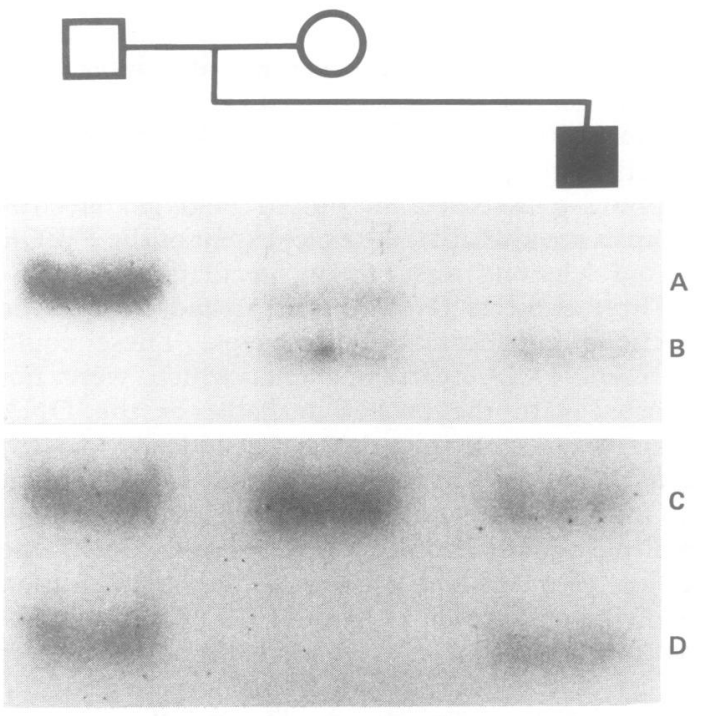

Figure 4 DNA polymorphism patterns in family 9. $(A, B)$ 6.5, 6.3 kb RFLPs identified with restriction endonuclease ScaI and probe pML34. (C,D) Two alleles for the multiallelic CMW1 probe detected with restriction endonuclease EcoRI.

found with only one of nine restriction enzymes. Against this explanation is the failure to find the same band in normal control DNA samples and its presence in two of 27 patients with PWS. One of these same two patients also showed a new EcoRI restriction fragment with a second, unrelated probe $(85(2 \cdot 4))$. To determine the significance of the $20 \mathrm{~kb}$ $B a m H I$ band will require mapping with additional DNA probes or cloning of this region or both. The above two cases, as well as one example of paternal allele loss shown by RFLP analysis (No 9, fig 4), provide further evidence for the proposal that PWS is the result of a mutation affecting the paternal allele. ${ }^{59}$ DNA polymorphic data from family studies in patient 9 further define the paternal abnormality to include the PWS specific locus identified by probe p3.21 (15q11.2), but not the multiallelic CMW1 probe which maps distal to the deletion region in PWS. ${ }^{9}$

In 10 family studies, normal parental patterns confirmed that DNA deletions were de novo mutations. This had been noted previously on cytogenetic analysis and a small number of DNA studies and is consistent with the sporadic nature of PWS. ${ }^{513}$ Diagnosis of PWS can be difficult since there are no distinguishing laboratory findings and the clinical spectrum varies. However, a combination of both cytogenetic and molecular analysis will increase the number of subjects who can be shown to have chromosome 15q11-13 specific defects.
This work was supported by the National Health and Medical Research Council of Australia. We are grateful to the Prader-Willi Association of Australia for help and cooperation in conducting this study. We thank Dr Brian Learoyd (Macquarie Hospital) and Sister Sue White (Adelaide Children's Hospital) for collecting blood from many of the patients, and Miss C Yeung for typing the manuscript. DNA paternity studies were obtained by Ms A Kearney.

1 Bray GA, Dahms WT, Sverdloff RS, Fiser RH, Atkinson RL, Carrel RE. The Prader Willi syndrome: a study of $\mathbf{4 0}$ patients and a review of the literature. Medicine (Baltimore) 1983;62:59-80.

2 Laurance BM. The Prader Willi syndrome. Matern Child Health 1985;10:106-9.

3 Kousseff BG, Burke CM. Familial Prader-Willi syndrome: new developments. Am $\mathcal{F}$ Med Genet 1987;28:79.

4 Ledbetter DH, Riccardi VM, Airhart SD, Strobel RJ, Keenan BS, Crawford JD. Deletions of chromosome 15 as a cause of the Prader Willi syndrome. N Engl f Med 1981;304:325-9.

5 Butler MG, Meaney FJ, Palmer CG. Clinical and cytogenetic survey of 39 individuals with Prader-Labhart-Willi syndrome. Am F Med Genet 1986;23:793-809.

6 Smith A. Chromosome findings in the Prader Willi syndrome. Aust NZ F Develop Disab 1986;12:13-28.

7 Donlon TA, Lalande M, Wyman A, Bruns G, Latt SA. Isolation of molecular probes associated with the chromosome 15 instability in the Prader Willi syndrome. Proc Natl Acad Sci USA 1986;83:4408-12.

8 Tasset DM, Hartz JA, Kao FT. Isolation and analysis of DNA markers specific to human chromosome 15. Am $\mathcal{F}$ Hum Genet 1988;42:854-66.

9 Nicholls RD, Knoll JHM, Butler MG, Karam S, Lalande M. Genetic imprinting suggested by maternal heterodisomy in non-deletion Prader Willi syndrome. Nature 1989;342:281-5.

10 Smith A, Simpson E. Dermatoglyphic analyses of 24 individuals with the Prader-Willi syndrome. F Ment Defic Res 1982;26:91-9.

11 Old JM, Higgs DR. Gene analysis. In: Weatherall DJ, ed. The thalassaemias. Methods in haematology vol 6. Edinburgh: Churchill Livingstone, 1983:74-102.

12 Gregory CA, Kirkilionis AJ, Greenberg CR, Chudley AE, Hamerton JL. Detection of molecular rearrangements in Prader-Willi syndrome patients by using genomic probes recognizing four loci within the PWCR. Am f Med Genet 1990;35:536-45.

13 Nicholls RD, Knoll JH, Glatt K, et al. Restriction fragment length polymorphisms within proximal $15 q$ and their use in molecular cytogenetics and the Prader-Willi syndrome. Am f Med Genet 1989;33:66-77.

14 Rich DC, Witkowski CM, Summers KM, van Tuinen $P$ Ledbetter DH. Highly polymorphic locus D15S24 (CMW-1) maps to 15pter-q13. Nucleic Acids Res 1988;16:8740.

15 Higgs DR, Wainscoat JS, Flint J, et al. Analysis of the human $\alpha$-globin gene cluster reveals a highly informative genetic locus. Proc Natl Acad Sci USA 1986;83:5165-9.

16 Yunis JJ. High resolution of human chromosomes. Science 1976;191:1268-70.

17 Seabright $M$. A rapid banding technique for human chromosomes. Lancet 1971;ii:971-2.

18 Smith A, Noel $M$. A girl with the Prader Willi syndrome and Robertsonian translocation 45,XX,t(14;15)(p11;q11) which was present in three normal family members. Hum Genet 1980;55:271-3.

19 Smith A, den Dulk G, Lipson A, Suter M. Classical Prader Willi syndrome with trisomy $15(\mathrm{pter} \rightarrow \mathrm{q} 12)$ plus de novo variant 15p11. Ann Genet (Paris) 1989;32:39-42.

20 Knoll JHM, Nicholls RD, Magenis RE, et al. Angelman syndrome: three molecular classes identified with chromosome 15q11-q13-specific DNA markers. Am f Hum Genet $1990 ; 47: 149-54$.

21 Donlon TA. Similar molecular deletions on chromosome 15q11.2 are encountered in both the Prader Willi and Angelman syndromes. Hum Genet 1988;80:322-8. 